\title{
THE ROLE OF SLEEP IN MIGRAINE ATTACKS
}

\author{
ELAINE INAMORATO *, SUZANMEIRE N. MINATTI-HANNUCH **, \\ ELIOVA ZUKERMAN ***
}

\begin{abstract}
SUMMARY - Migraine attacks may be precipitated by sleep deprivation or excessive sleep and sleep is also associated with relief of migraine attacks. In view of this variable relationship we studied the records of 159 consecutive outpatients of our Headache Unit. In 121 records there was reference to sleep involvement, in $55 \%$ by a single form and in $45 \%$ by more than one form. When only one form was related, relief was most common (70\%). $30 \%$ of that group of patients had the migraine attack precipitated by sleep, $24 \%$ by deprivation and $6 \%$ by sleep excess. When the effects of sleep were muitiple, these effects were as expected logically in 65\%: «in accordance» group (e.g attack precipitated by sleep deprivation and relieved by sleep onset. In a second group, («conflicting») where the involvement was not logical, there were three different combinations of sleep involvement, possibly due to more than one pathophysiological mechanism.
\end{abstract}

KEY WORDS: migraine, sleep, precipitating factor, sleep deprivation, sleep excess, relieving factor, worsening factor.

\section{Papel do sono em crises de enxaqueca.}

RESUMO - Crises de enxaqueca podem ser precipitadas por deprivação ou excesso de sono e o sono também se encontra associado ao alívio de crises de enxaqueca. Dada essa variabilidade de relação, estudamos os registros de 159 pacientes de ambulatórío vistos consecutivamente no SITC. Em 121 havia referência a relação com o sono, em 55\% de uma só maneira e em 45\%, de mais de uma. Quando apenas um modo foi relatado, o alivio foi mais frequente (70\%). 30\% desse grupo de pacientes apresentavam crise de enxaqueca precipitada pelo sono, $24 \%$ por deprivação e 6\% por excesso de sono. Quando eram múltiplos os efeitos do sono, eram eles os logicamente esperados em 65\%: grupo «de acordo» (exemplo: crise precipitada por deprivação de sono e aliviada no início do sono). Em um segundo grupo («conflitante») a relação não era lógica, três tipos diversos de combinação do relacionamento tendo sido encon. trados, possivelmente devido à participação de mais de um mecanismo fisiopatológico.

PALAVRAS-CHAVE: enxaqueca, sono, fator precipitante, deprivação de sono, excesso de sono, fator de alívio, fator de piora.

The relationship between migraine and sleep has long been recognized 2,7-9,13, 14,17,18. Migraine attacks may be precipitated by sleep deprivation or excessive sleep $4,7-9,13$, and sleep is also associated with relief of migraine attacks $2,3,13,20$. In view of this variability, we decided to study the various types of relationship between migraine and sleep in a group of migraine sufferers.

\section{PATIENTS AND METHODS}

The standard records of 159 consecutive outpatients of the SITC, from January 1989 to April 1990 were studied. In addition to demographic data, the following features of pain

Sector for Investigation and Treatment of Headaches (SITC), Department of Neurology, Escola Paulista de Medicina: * Mestranda; ** Médica Assistente-Doutor; *** Professor Adjunto, Chefe do srTC. Aceite: 8-junho-1993.

Dra. Suzanmeire Negro Minatti-Hannuch - Av. Profa. Ida Kolb 225, Bloco 3, Apto. 182 02508-000 São Paulo SP - Brasil. 
were considered: site, duration, intensity, precipitating, preceding, relieving, and exacerbating factors. The diagnosis was based on the IHS Classification 6 . The patients ages ranged from 9 to 67 (mean 35.5) years, 131 were female and 28 male. The diagnosis was migraine without aura in 100 , migraine with aura in 50 , and 9 with both forms.

The patients were grouped according to the role of sleep.

Group 1. Patients where sleep participated of a single form whether as a precipitating, relieving or exacerbating factor.

Group 2. Patients where sleep participated with more than one form. Sub-group 2A was formed by those patients in whom sleep deprivation precipitates a migraine attack and sleep relieves it, and those where excess of sleep precipitates a migraine attack and sleep worsens it. Sub-group 2B was formed by those patients in whom sleep deprivation and excess of sleep precipitate migraine attacks, those in whom sleep both precipitates and relieves migraine attacks, those in whom sleep deprivation and sleep excess precipitate migraine attacks and sleep relieves it, and those where sleep deprivation precipitates a migraine attack and sleep worgens it.

\section{RESULTS}

The main results are shown in Tables 1 to 3 .

Sleep was related to migraine in a single form 67 patients (55\%), two forms in 46 (38\%) and three forms in $8(7 \%)$ of the patients.

\section{COMMENTS}

As can be seen from our results, sleep had some relation to migraine attacks in $76 \%$ of our patients, whether as a precipitating, relieving or exacerbating factor. In over half of our patients $(55 \%)$, the relationship was with a single form of sleep and in $70 \%$ sleep relieved the migraine attack. When it participated in a single form, relief was the most common form of participation. These results are in accordance with other authors $2,15,20$.

Table 1. Sieep participation during migraine attacks with regard to sex.

\begin{tabular}{|c|c|c|c|c|}
\hline \multicolumn{5}{|c|}{ Sleep Participation } \\
\hline Sex & Yes & No & Total & $\%$ Yes \\
\hline Male & 25 & 3 & 28 & 89 \\
\hline Female & 96 & 35 & 131 & 73 \\
\hline Total & 121 & 38 & 159 & 76 \\
\hline
\end{tabular}

Table 2. Sleep participation as an unique form.

\begin{tabular}{|c|c|c|}
\hline \multirow[b]{2}{*}{ Factors } & \multicolumn{2}{|c|}{ Patients } \\
\hline & $\mathbf{N}$ & $\%$ \\
\hline Precipitating & 20 & 30 \\
\hline deprivation & 16 & 24 \\
\hline excess & 4 & 6 \\
\hline Relieving & 47 & 70 \\
\hline Total & 67 & 100 \\
\hline
\end{tabular}


Table 3. Patients in whom sleep participates in more than one form in migraine attacks.

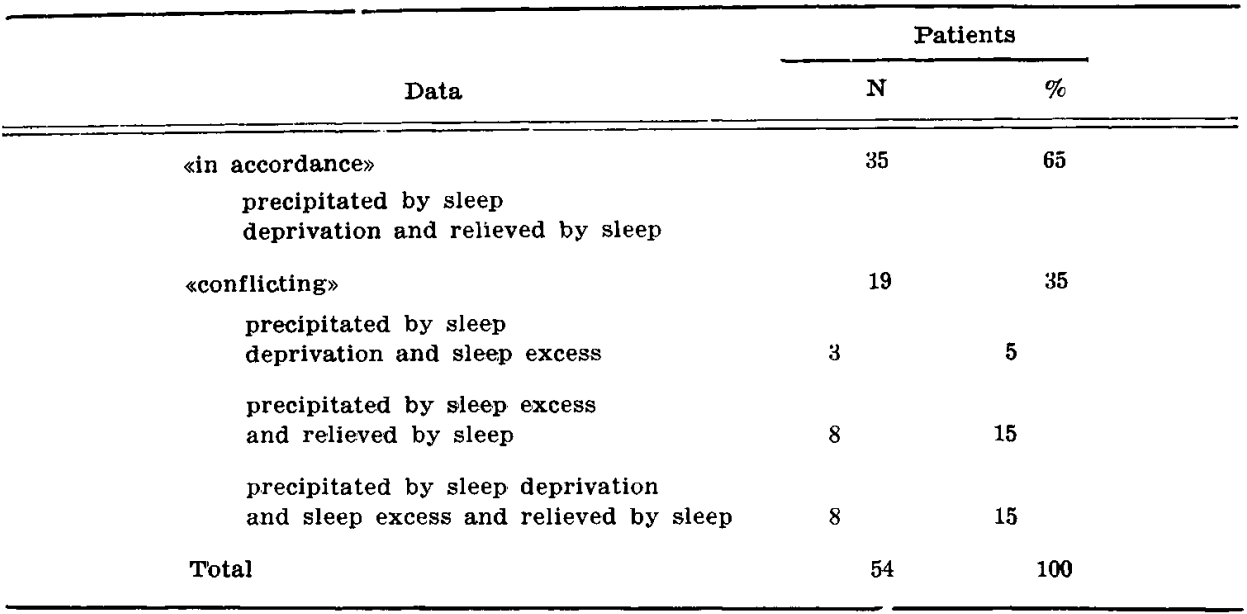

We observed also that when sleep acts as a precipitating factor, it was usually sleep deprivation that stimulated the attack. The information regarding precipitating and relieving factors was obtained by spontaneous reference by the patient. When the patient did not volunteer all of this information, the physician would mention other possible factors which might be related to migraine attacks. It is important to consider this methodology, since in a previous report, where we only considered the information spontaneously volunteered by the patient, we observed that sleep acted as a precipitating factor in $3 \%$ of patients 16 .

In some situations, particularly when sleep participates in more than one form, it is possible that different pathophysiological mechanisms could be invol. ved. For example when sleep excess precipitates an attack and onset of sleep aborts or relieves it. On the other hand, when sleep deprivation precipitates and sleep onset relieves the migraine attacks, it is likely that only one mechanism is activated. It is based on these hypotheses that we divided the patients into two groups, "in accordance" and "conflicting". In the "in accordance" group there were no instances of sleep excess precipitating an attack which was wor. sened by sleep onset. In the "conflicting" group, there were no cases of sleep deprivation precipitating an attack which was worsened by sleep onset nor were there any patients in which both sleep deprivation and excess precipitated attacks and sleep onset relieved and worsened attacks.

It is known that the migraine attacks may occur during the nocturnal sleep period or following a short period of diurnal sleep, but only after periods of stage III and IV or REM sleep 8. During the course of nocturnal sleep, the periods of REM sleep gradually increase in length especially if sleep is extended into the morning 11. In some patients sleep deprivation precipitated a migraine attack. This may be due to a decrease in the pain threshold, probably as a result of alterations in neurotransmitter systems 19 . On the following night, there is a predominance of slow wave sleep, and this readjustment may be the way that sleep relieves the migraine attack 1,5 .

The cyclic nature of migraine may have relationship with some chronobiological phenomena 14. Some authors imply a vulnerability of the central nervous system. There may also be dysfunction of the endocrine system and neurotransmitter processes connected with pain production 12. Another group of authors emphasize the chronobiological relationship between headaches and behavioral disturbance (for example: the pre-menstrual tension syndrome), postulating that supposediy different disorders can be brought about by dysfunction of the central "clock" and the chain of related psychoneuroendocrinological events 10.

Additional studies are required to understand the features of the relationship between sleep and migraine. 


\section{REFERENCES}

1. Berger RJ, Oswald I. Effects of sleep deprivation on behavior, subsequent sleep and dreaming. J Ment Sci 1962, 108:457-465.

2. Blau JN. Resolution of migraine attacks: sleep and the recovery phase. J Neurol Neurosurg Psychiatry 1982, 45:223-226.

3. Blau JN, Thavapplan M. Preventing migraine: a study of precipitating factors. Headache 1988, 28:481-483.

4. Blau JN. Sleep deprivation headache. Cephalalgia 1990, 10:157-160.

5. Borbely AA, Bauman F, Brandus D, Strauch I, Lehmann D. Sleep-deprivation: effect on sleep stages and EEG power density in man. Electroenceph Clin Neurophysiol 1981, 51: 483-493.

6. Classification and diagnostic criteria for headache disorders, cranial neuralgias and facial pain. Cephalalgia 1988, (Suppl 17):19-28.

7. Dexter JD, Weitzman ED. The relationship of nocturnal headaches to sleep stage patterns. Neurology 1970, 20:513-518.

8. Dexter JD. The relationship between stage III +IV + REM sleep and arousals with migraine. Headache 1979, 19:364-369.

9. Dexter JD, Riley TL. Studies in nocturnal migraine. Headache 1975, 15:51-62.

10. Falaschi P, Buongiorno T, Agnoli A. Chrononeuroendocrine perspectives of ACTH and related peptides, Cephalalgia 1983, 3(Suppl 1):111-116.

11. Feinberg I, Fein G, Floyd TC. EEG patterns during and fo:lowing extended sleep in young adults. Electroenceph Clin Neurophysiol 1980, 50:467-476.

12. Ferrari E, Canepari C, Bossolo PA, Vailati A, Martignoni E, Micieli G, Nappi G. Changes of biological rhythms in primary headache syndromes. Cephalalgia 1983, 3(Suppl 1):58-68.

13. Gans M. Treating migraine by «sleep-rationing». J Nerv Ment Dis 1951, 113:405-429.

14. Kayed K, sjaastad $O$. Nocturnal and early morning headaches. Ann Clin Res 1985, 17: 243-246.

15. Minatti-Hannuch SN, Inamorato $\mathrm{E}$, Zukerman $E$. Sleep as a relieving factor in migraine treatment: a study in a emergency headache unit. Cephalalgia 1991, 11(Suppl 11 ):145.

16. Minatti-Hannuch SN, Zukerman E, Inamorato E. Fatores desencadeantes das crises de enxaqueca na infância. J Pediatria 1990, 66:127-129.

17. Parrino L, Pietrini V, Spaggiari MC, Terzano MG. Acute confusional migraine attacks resolved by sleep: lack of significant abnormalities in post ictal polysomnograms. Cephalalgia 1986, 6:95-100.

18. Sahota PK, Dexter JD. Sleep and headache syndromes: a clinical review. Headache 1990, 30:80-84.

19. Ukponmwan OE, Rupreht J, Dzoljic MR. REM sleep deprivation decreases the antinociceptive property of enkephalinase-inhibition, morphine and cold-water-swin. Gen Pharmac 1984, $15: 255-258$.

20. Wilknson $\mathbf{M}$, Willians $\mathbf{K}$, Leyton $\mathbf{M}$. Observations on the treatment of the acute attack of migraine. Res Clin Stud Headache 1978, 6:141-146. 